\title{
Effect of immobilized phosphate solubilizing bacteria on wheat growth and phosphate uptake
}

\author{
M. Schoebitz ${ }^{1}$, C. Ceballos ${ }^{1}$ and L. Ciampi ${ }^{1 *}$ \\ ${ }^{\text {I}}$ Facultad de Ciencias Agrarias, Instituto de Producción y Sanidad Vegetal, Universidad Austral de Chile, Campus Isla Teja, \\ Valdivia, Chile.*Corresponding autor: lciampi@uach.cl
}

\begin{abstract}
A study was performed to investigate the efficiency of rhizobacteria on solubilization of rock phosphate and their assimilation by wheat plants in quartz sand potted experiments. Two phosphate solubilizing bacteria, $P$. fluorescens and Serratia sp. were encapsulated in sodium alginate and potato starch beads and selected to investigate the variation on $\mathrm{pH}$ values, the enzymatic activity of alkaline and acid phosphatase and phosphate solubilization in Pikovskaya liquid medium. A relation between $\mathrm{pH}$ diminution and $\mathrm{P}$ solubilization was found. P solubilization of 89 and $93 \mu \mathrm{gL}^{-1}$ was observed with immobilized phosphate solubilizing bacteria, which was significantly higher compared to autoclaved alginate-starch beads. Higher values around $64 \%$ in P uptake by wheat plants after 60 days of growth was observed with immobilized P. fluorescens $+3.25 \mathrm{ppm}$ of $\mathrm{P}$. The results demonstrated that inoculation of the immobilized rhizobacteria is a promising option for inoculant carriers to increase P level in plants wheat and could be an innovative technique for application in agricultural industry.
\end{abstract}

Keywords: Inoculant carriers, rhizobacteria, bioencapsulation, rock phosphate, solubilization.

\section{Introduction}

Immobilization of bacterial cells has been widely used in agriculture, pharmaceutical, food and other industries to achieve a protective structure or a capsule allowing immobilization, protection, release and functionalization of active ingredients. Therefore less exposed to adverse environmental factors since encapsulation tends to stabilize cells, potentially enhancing their viability and stability in the production, storage and handling of cultures and also confers additional protection during rehydration and lyophilisation (Kim et al., 1996). Additionally, introduction of microbial inoculants into soil have demonstrated that some inoculants can improve plant uptake of nutrients and thereby increase 
the use efficiency of applied chemical fertilizers (Adesemoye and Kloepper, 2009). In this regard the use rhizobacteria has a potential role in developing sustainable systems for crop production (Bashan et al., 2004). However, direct inoculation of free phosphate solubilizing bacteria (PSB) into soil is not easy to maintain cells survival around plants roots because it is susceptible to a variety of environmental soil variation such as temperature, humidity and salt stress (Wu et al., 2012). Variability of PSB inoculation on plant is mainly due to the quality in the inoculants formulations containing an effective bacterial strain and can determine the success or failure of a biological agent. Therefore, the goal will be to find an adequate formulation to convert a promising bacteria strain into a commercial inoculant product (Bashan, 1998).

Research on PSB have mainly been focused on liquid media or peat to introduce bacteria into the soil, although a few have been carried out for immobilized rhizobacteria in biopolymer gels being this method a satisfactory alternative to be employed to solubilize rock phosphate. Cells immobilization in alginatestarch has been demonstrated to be more advantageous to improve cells survival and reducing the risk of decreased survival allowing long term storage of bacterial inoculum (Schoebitz et al., 2012; Cassidy et al., 1996). A major role of inoculant carrier is to provide more suitable microenvironment for the prolonged survival into the soil (Rekha et al., 2007).

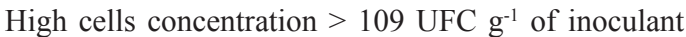
and to improve the cells survival during storage period to ensure good protection of PSB in soil are the key factors to ensure positive response on plant inoculation (Fages, 1992).

The principle of immobilization of rhizobacteria is to protect the microorganisms introduced to soil and to ensure a gradual and prolonged release (Kim et al., 2012; John et al., 2011). The degradation rate of the encapsulation matrix used will direct relation to the biological activity of the microorganisms. Beads are stored at room temperature for a long period. These inoculants can be improved by incorporating essential nutrients for growth of bacteria, so as to transform every bead in bioreactors, which are capable of increasing the initial number of immobilized bacteria inoculated into the soil. The aim of this study was to measure the effects of immobilized bacteria on solubilization of insoluble inorganic phosphate and their assimilation by wheat plants in potted experiments.

\section{Materials and Methods}

\subsection{Micro-organisms and culture conditions}

Pseudomonas fluorescens C139 and Serratia sp T3 originally isolated from rhizosphere of Rubus ulmifolius and Triticum aestivum respectively, were provided by the Facultad de Ciencias Agrarias, Universidad Austral de Chile. Both strains were grown in $100 \mathrm{~mL}$ of sterile trypticase soy broth adjusted to $\mathrm{pH}$ 6.5. Cultures were performed on a rotary shaker $(150$ rev $\mathrm{min}^{-1}$ ) at $30^{\circ} \mathrm{C}$ to harvest after $24 \mathrm{~h}$ of growth.

\subsection{Immobilization process}

Matrix solution was prepared by mixing sodium alginate and potato-starch in distilled water in the following way. Three grams of sodium alginate Gelygum 7208 (Gelymar, Chile) were dissolved in 100 $\mathrm{mL}$ of distilled water and stirred for $30 \mathrm{~min}$ to obtain a homogeneous solution. $47 \mathrm{~g}$ of standard potato-starch (Industrias Prosecor, Chile) was added to the sodium alginate solution. The matrix was then stirred for 30 min for homogenization. $30 \mathrm{~mL}$ of the culture was centrifuged $\left(8720 \mathrm{~g}\right.$ for $10 \mathrm{~min}$ at $\left.4^{\circ} \mathrm{C}\right)$. The pellet was re-suspended in $3 \mathrm{~mL}$ of $1 \%$ peptone and the suspension was mixed with $30 \mathrm{~mL}$ of matrix solution. The matrix mixture containing cells was transferred to the syringe $(50 \mathrm{~mL})$. The matrix solution was placed in a pump-syringe and dropped into sterile calcium chloride solution $\left(15 \mathrm{~g} \mathrm{~L}^{-1}\right)$. Gelling of alginate-starch beads was completed after $30 \mathrm{~min}$ in contact with the 
calcium solution. The collected humid beads were stored in sealed plastic flasks at $4^{\circ} \mathrm{C}$ (Schoebitz et al., 2012).

\subsection{Bead bacterial counts}

Ten dry beads were placed into $10 \mathrm{~mL}$ of sterile physiological solution for $30 \mathrm{~min}$ and after were dissolved in $10 \mathrm{~mL}$ sterile sodium citrate solution $\left(60 \mathrm{~g} \mathrm{~L}^{-1}\right)$ for $30 \mathrm{~min}$ at room temperature in a rotary shaker until to complete dissolution then the number of released bacteria was determined by the standard plate count method in plate count agar.

\subsection{Determination of solubilization index}

The ability of the rhizobacteria to solubilize insoluble phosphate was primarily described by the solubilization index (SI): Ratio of total diameter (colony + halo zone) to colony diameter on Pikovskaya (PVK) agar incubated at $28{ }^{\circ} \mathrm{C}$ (Edi-Premono et al., 1996). Three replicates measurement was carried out after 3 days of incubation.

\subsection{Mineral P solubilization in liquid media}

The efficiency of Serratia sp. and P. fluorescens immobilized for $\mathrm{P}$ solubilization was measured with PVK liquid media. The $\mathrm{pH}$ of each medium was adjusted to 7.5 before autoclaving. Each Erlenmeyer flasks contained $100 \mathrm{~mL}$ of PVK inoculated with $4 \mathrm{~g}$ of alginate-starch beads. The flasks were incubated for 3 days at $28{ }^{\circ} \mathrm{C}$ with shaking $\left(150 \mathrm{rev} \mathrm{min}^{-1}\right)$ on a rotary shaker. Alginate-starch beads were separated from the PVK medium. Quantitative spectrophotometric analysis of the soluble phosphate was measured according to standard protocol (Murphy and Riley, 1962).

\subsection{Phosphatase activity}

Phosphatase activity was determined using pnitrophenyl phosphate disodium (PNPP, $0.115 \mathrm{M}$ ) as substrate. For the assay, $2 \mathrm{~mL}$ of $0.5 \mathrm{M}$ sodium acetate buffer adjusted to pH 6.5 and 11 (Naseby and Lynch, 1997) and $0.5 \mathrm{~mL}$ of substrate were added to $0.5 \mathrm{~mL}$ of PVK medium incubated at $37^{\circ} \mathrm{C}$ for $90 \mathrm{~min}$. The reaction was stopped by cooling at $2{ }^{\circ} \mathrm{C}$ for $15 \mathrm{~min}$. Then $0.5 \mathrm{~mL}$ of $0.5 \mathrm{M} \mathrm{CaCl}_{2}$ and $2 \mathrm{~mL}$ of $0.5 \mathrm{M} \mathrm{NaOH}$ were added and the mixture centrifuged at $4000 \mathrm{rev}$ $\mathrm{min}^{-1}$ for $5 \mathrm{~min}$. The p-nitrophenol (PNP) formed was determined by spectrophotometry at $398 \mathrm{~nm}$ (Tabatabai and Bremmer, 1969). Controls were made in the same way, although the substrate was added before the $\mathrm{CaCl}_{2}$ and $\mathrm{NaOH}$.

\subsection{Mineral P solubilization in quartz sand}

In order to observe the effect of $\mathrm{P}$ solubilization in quartz sand, 20 beads of Serratia sp. and P. fluorescens were introduced intotheflasks contained 10, 20 and 40 ppm of rock phosphate. The flasks contained $20 \mathrm{~g}$ of quartz sand were incubated at $28^{\circ} \mathrm{C}$. The beads were added to the soil surface and then they were mixed into the soil using s sterile metal spatula. After one week the available $\mathrm{P}$ in quartz sand was measured according to Murphy and Riley (1962).

\subsection{Plant-immobilized bacteria assay}

The experiment was carried out in a plant growth room in order to evaluate the effects of rhizobacteria on plant growth and P uptake of wheat. Three-day-old seedlings of wheat were used in all the experimented. Seed were disinfected in $2 \%$ sodium hypochlorite for $30 \mathrm{~min}$ and rinsing 3 times with sterile distilled water. Disinfected seeds were transferred to Petri dishes with $20 \%$ water-agar and incubated for 3 days at $30^{\circ} \mathrm{C}$ in the dark conditions. Then, 3-day-old seedlings were planted individually in each polyethylene pot.

The $\mathrm{P}$ amount of quartz sand was removed soaking in $\mathrm{HCl}(3 \mathrm{M})$ during $14 \mathrm{~h}$. Then the $\mathrm{HCl}$ was eliminated and the excess was removed with abundant tap water. Then the quartz sand was dried at $35^{\circ} \mathrm{C}$ for 3-5 days. 


\subsection{P fertilization}

$\mathrm{P}$ amendments were applied to each pot using $100 \mathrm{~mL}$ of Hoagland nutrient solution (Hoagland and Arnon, 1950) per week with different regimes of soluble $P$ and insoluble phosphate rock. Six different $\mathrm{P}$ regimes were evaluated: (1) Solution without soluble P and phosphate rock (2) Solution without soluble P: $7.5 \mathrm{~mL}$ of $\mathrm{Ca}\left(\mathrm{NO}_{3}\right)_{2} * 4 \mathrm{H}_{2} \mathrm{O}(1 \mathrm{M}), 3 \mathrm{~mL}$ of $\mathrm{MgSO}_{4} * 7 \mathrm{H}_{2} \mathrm{O}(1$ $\mathrm{M}), 10 \mathrm{~mL}$ of $\mathrm{K}_{2} \mathrm{SO}_{4}(0.5 \mathrm{M}), 1 \mathrm{~mL}$ of iron chelate $(0.1$ $\%)$ and $1 \mathrm{~mL}$ of trace elements $\left(\mathrm{MnCl}_{2} * 4 \mathrm{H}_{2} \mathrm{O} 1.8 \mathrm{~g} \mathrm{~L}^{-1}\right.$; $\mathrm{H}_{3} \mathrm{BO}_{3} 3.0 \mathrm{~g} \mathrm{~L}^{-1} ; \mathrm{ZnSO}_{4} * 7 \mathrm{H}_{2} \mathrm{O} 0.3 \mathrm{~g} \mathrm{~L}^{-1} ; \mathrm{CuSO}_{4} * 5 \mathrm{H}_{2} \mathrm{O}$ $0.1 \mathrm{~g} \mathrm{~L}^{-1}$ and $\mathrm{H}_{2} \mathrm{MoO}_{4} 0.1 \mathrm{~g} \mathrm{~L}^{-1}$ ). (3) Solution $3 \mathrm{ppm}$ soluble P: $5 \mathrm{~mL} \mathrm{Ca}\left(\mathrm{NO}_{3}\right)_{2} * 4 \mathrm{H}_{2} \mathrm{O}(1 \mathrm{M}), 5 \mathrm{~mL}$ of $\mathrm{KNO}_{3}$ $(1 \mathrm{M}), 1 \mathrm{~mL}$ of $\mathrm{KH}_{2} \mathrm{PO}_{4}(1 \mathrm{M}), 4 \mathrm{~mL}$ of $\mathrm{MgSO}_{4} * 7 \mathrm{H}_{2} 0$ $(1 \mathrm{M}), 1 \mathrm{~mL}$ of iron chelate $(0.1 \%)$ and $1 \mathrm{~mL}$ of trace elements. (4) Solution $3.25 \mathrm{ppm}$ soluble P: similar that solution 3 with $1.08 \mathrm{~mL}$ of $\mathrm{KH}_{2} \mathrm{PO}_{4}(1 \mathrm{M})$ and 1.75 $\mathrm{mL}$ of $\mathrm{KCl}(0.68 \mathrm{M})$.(5) Solution $3.5 \mathrm{ppm}$ soluble $\mathrm{P}$ : similar that solution 3 with $1.162 \mathrm{~mL}$ of $\mathrm{KH}_{2} \mathrm{PO}_{4}(1 \mathrm{M})$ and $1.5 \mathrm{~mL}$ of $\mathrm{KCl}(0.68 \mathrm{M})$. (6) Solution $4 \mathrm{ppm}$ soluble P: similar that solution 3 with $1.323 \mathrm{~mL}$ of $\mathrm{KH}_{2} \mathrm{PO}_{4}$ $(1 \mathrm{M})$ and $1 \mathrm{~mL}$ of $\mathrm{KCl}(0.68 \mathrm{M})$. The treatments 2-6 were supplemented with phosphate rock powder (17$19 \% \mathrm{P}_{2} \mathrm{O}_{5}$ ) provided by Bifox (Compañía minera de fosfatos naturales Bifox Ltda, Santiago, Chile). Pots were fertilized with $10 \mathrm{ppm}$ of insoluble rock powder phosphate, except pots without $P$.

\subsection{Inoculation assay}

The pots were prepared using $800 \mathrm{~g}$ quartz sand $(0.15 \mathrm{~mm})$. Four germinated Pandora-INIA spring wheat cultivar were planted in each polyethylene pot ( $8 \mathrm{~cm}$ diameter, $13 \mathrm{~cm}$ height). For the inoculation treatments, 3 alginate-starch beads were inoculated 2 $\mathrm{cm}$ near to the germinated seedlings. Control plants received 3 autoclaved alginate-starch beads. The growth period of wheat was of 8 weeks in a growth chamber at $25^{\circ} \mathrm{C}$ with $16 \mathrm{~h}$ light and $8 \mathrm{~h}$ darkness. $200 \mathrm{~mL}$ of sterilized water was added per week in quartz sand to maintain soil moisture levels near field capacity. Growth promotion effects of bacterial treatments were assessed by measuring shoot and root dry weight, plant height and $\mathrm{P}$ nutrient uptake of plants. The dry weights were determined by using an oven at $70^{\circ} \mathrm{C}$ for $48 \mathrm{~h}$. The $\mathrm{P}$ contents in the wheat plant were assayed by molybdate-blue method (Murphy and Riley, 1962).

\subsection{Statistical analysis}

Plant growth data were analyzed by one-way ANOVA and post-hoc mean separation was performed by Duncan's multiple range test at $p \leq 0.05$ by using the software SPSS version 19.0.

\section{Results and Discussion}

Average weight of the wet alginate-starch bead was $56.4 \pm 3.4 \mathrm{mg}$ with an average diameter of fresh bead $4.11 \pm 0.37 \mathrm{~mm}$ and initial bacteria concentration of the $2.72 \times 109 \mathrm{CFU} \mathrm{g}^{-1}$ and $2.17 \times 109 \mathrm{CFU} \mathrm{g}^{-1}$ for P. fluorescens and Serratia sp. respectively. Alginate beads are structured as a loose network filled with a large quantity of water (97-98\%). Thus, using only alginate for microbial cells immobilization, it would not be adequate to protect bacteria during immobilization process, drying and storage. However, applying starch an inexpensive material for cells immobilization and one of the most abundant natural biopolymers (Hickman, 1999), would improve cells survival on storage conditions (Schoebitz et al., 2012) since this filler material to serve as a carbon source to the bacteria. Additionally, microbial cells immobilization helps to increase the survival rate and slow cells release into the soil (Rekha et al., 2007).

P. fluoresens and Serratia sp. immobilized on alginatestarch beads were evaluated to solubilize inorganic phosphate and autoclaved beads produced no clear halos on Pikovskaya agar plates (Figure 1).

The results of solubilization index of $P$. fluorescens 
$(4.9 \pm 0.4 \mathrm{~mm})$ and Serratia sp. $(4.5 \pm 0.4 \mathrm{~mm})$, demonstrated that both had high phosphate solubilizing ability. However, the production of a halo on Pikovskaya agar plates should not be considered the sole test for $\mathrm{P}$ solubilization; an additional test in Pikovskaya liquid media to assay P dissolution should be performed (Bashan et al., 2012). Thus, the results of P solubilization capacity of $P$. fluoresens and Serratia

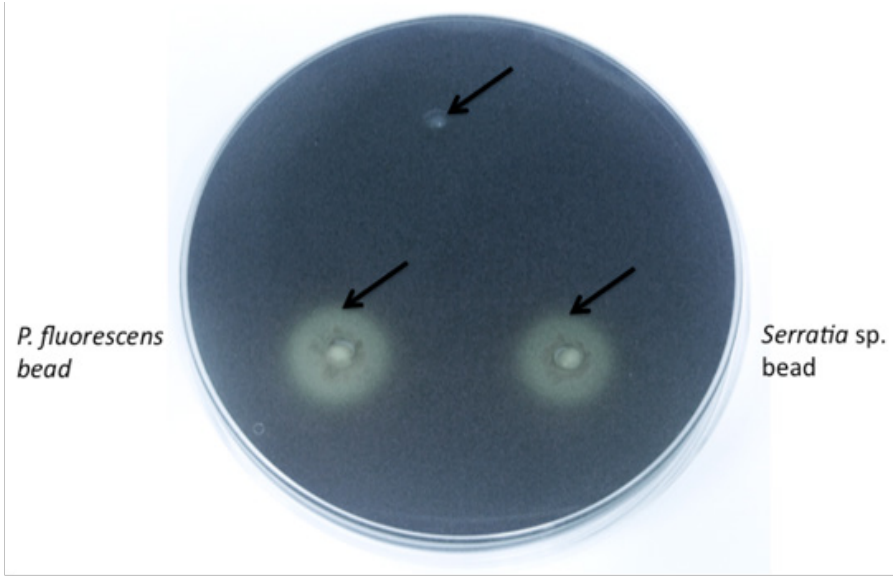

Figure 1. Extracellular inorganic phosphate solubilization assay in Pikovskaya agar plates. P. fluorescens and Serratia sp. immobilized cells were inoculated inside wells performed on the agar surface and P-solubilization was measured after 3 days incubation at $28^{\circ} \mathrm{C}$. Control is trial with autoclaved bead.

sp. in liquid medium revealed that concentration of soluble phosphorus in the culture ranged between $89 \pm 8.5$ and $93 \pm 1.1 \mathrm{mg} \mathrm{L}^{-1}$ respectively. In liquid medium the immobilized bacteria lowered the initial $\mathrm{pH}$ value of 7.5 to 5.9 after 3 days of incubation at $28^{\circ} \mathrm{C}$ (Table 1) The magnitude of the results reported could be compared to encapsulated Enterobacter sp.where the amount of soluble phosphorus was 69 $\mathrm{mg} \mathrm{L}^{-1}$ achieved after $50 \mathrm{~h}$ fermentation (Vassilev et al., 1997). It is accepted that solubilization of insoluble $\mathrm{P}$ compound is due to the excretion of microbial metabolites such as organic acids. In addition to acid production, other mechanisms can cause phosphate solubilization (Nautiyal et al., 2000). PSB are common in the rhizosphere and secretion of phosphatases are common method of facilitating the conversion of insoluble forms of P to plant available forms (Rodriguez and Fraga, 1999). In this aspect, we found an acid and alkaline phosphatase activity on P. fluoresens and Serratia sp. in comparison to non-inoculated (control). Therefore, we noticed a clear connection between the decrease in $\mathrm{pH}$ values, increase phosphatase activity and $\mathrm{P}$ available on Pikovskaya liquid medium. After use $\mathrm{HCl}$ to remove de $\mathrm{P}$ content on quartz sand, the final amount of nutrients was $12.6 \mathrm{ppm}$ for nitrogen; $0.2 \mathrm{ppm}$ for phosphorus; $4.7 \mathrm{ppm}$ for potassium at $\mathrm{pH}$ value of 5.5.The immobilized bacteria were effective in dissolving inorganic phosphate since P. fluorescens and Serratia sp. immobilized in alginate-starch beads, were able to acidify the Pikovskaya 's broth. 
Table 1. Effect of inoculation by immobilized phosphate solubilizing bacteria on bacterial growth, solubilization index, phosphatase production and P solubilization on rock phosphate solubilization.

\begin{tabular}{|c|c|c|c|c|c|c|}
\hline & Bacterial growth & Solubilization & pH & Acid phosphatase & Alkaline phosphatase & P solubilization \\
\hline & $\left(\mathbf{A}_{660}\right)$ & index $(\mathrm{mm})^{2}$ & & $\left(\mu\right.$ moles PNF $\left.\mathrm{mL}^{-1} \mathbf{h}^{-1}\right)$ & $\left(\mu\right.$ moles PNF mL $\left.\mathbf{m}^{-1} \mathbf{h}^{-1}\right)$ & $\left(\mu \mathrm{g} \mathrm{mL} L^{-1}\right)$ \\
\hline ontrol $^{1}$ & $0 \pm 0$ & $0 \pm 0$ & $6.7 \pm 0.0$ & $0 \pm 0$ & $0 \pm 0$ & $0 \pm 0$ \\
\hline fluorescens & $0.8 \pm 0.03$ & $4.9 \pm 0.39$ & $5.9 \pm 0.02$ & $5.9 \pm 0.66$ & $3.0 \pm 0.92$ & $89.0 \pm 8.5$ \\
\hline erratia sp. & $0.8 \pm 0.04$ & $4.6 \pm 0.42$ & $5.9 \pm 0.08$ & $5.7 \pm 0.32$ & $3.2 \pm 0.49$ & $93.0 \pm 1.1$ \\
\hline
\end{tabular}

${ }^{1}$ Autoclaved beads. ${ }^{2}$ Solubilization index in PVK agar plates $=$ Total diameter (Colony + halo zone $) /$ colony diameter. Bacterial growth, $\mathrm{pH}$, phosphatases and P solubilization were measured in PVK liquid medium. Values are expressed as means \pm standard deviation of three independent data.

In order to evaluate the amount of inorganic phosphate applied into quartz sand, the activity of immobilized bacteria was measured using as criteria P solubilization after 7 days of application. The P solubilization was improved by the introduction of Serratia sp. to the quartz sand compared to non-inoculated control. (Table 2).
Plant growth promotion by rhizobacterias is well documented under laboratory conditions (Nico et al., 2012; Schoebitz et al., 2009a). Nevertheless, only some works about this subject of encapsulated rhizobacterias inoculation on plants are available (Rekha et al., 2007; Vassilev et al., 2001). This experiment was carried out in a plant growth room in order to evaluate the effects of $P$. fluorescens and Serratia sp. immobilized on wheat

Table 2. Solubilized P by immobilized $P$. fluorescens and Serratia sp. on quartz sand after 7 days of incubation at 10,20 and $40 \mathrm{ppm}$ of rock phosphate.

\section{P solubilization $\left(\mu \mathrm{g} \mathrm{mL} \mathbf{L}^{-1}\right)$}

\begin{tabular}{lccc} 
& 10 & 20 & 40 \\
\hline Control $^{1}$ & $1.9 \pm 0.11$ & $1.9 \pm 0.05$ & $1.4 \pm 0.19$ \\
P.fluorescens & $2.1 \pm 0.90$ & $1.9 \pm 0.20$ & $1.4 \pm 0.06$ \\
Serratia sp. & $10.7 \pm 0.57$ & $11.1 \pm 0.05$ & $11.7 \pm 0.44$
\end{tabular}

${ }^{1}$ Autoclaved beads. Values are expressed as means \pm standard deviation of three independent data. 
growth and $\mathrm{P}$ uptake. Plant growth promotion was evidenced by the increased of shoot length and $\mathrm{P}$ uptake under different treatments compared to the control treatment (autoclaved beads). P. fluorescens $+3.25 \mathrm{ppm}$ of inorganic phosphate showed significant $(p<0.05)$ higher values around $64 \%$ in $\mathrm{P}$ uptake compared to the control after 60 days of inoculation (Table 3).
The immobilized P. fluorescens and Serratia sp. + $3.5 \mathrm{ppm}$ of inorganic phosphate showed higher data of $23 \%$ and $18 \%(p<0.05)$ in the shoot length than the control treatment,respectively. The answer on $\mathrm{P}$ uptake was also positiveto the beads inoculation, since $\mathrm{P}$ absorption was significantly $(p<0.05)$ higher in plants inoculated with Serratia sp. After 60 days of

Table 3. Effect of inmobilization of phosphate solubilizing bacteria on growth parameters and total $\mathrm{P}$ of plant wheat.

\begin{tabular}{|c|c|c|c|c|}
\hline Treatments & $\begin{array}{c}\text { Shoot dry } \\
\text { (g) }\end{array}$ & $\begin{array}{c}\text { Root dry } \\
\text { (g) }\end{array}$ & $\begin{array}{c}\text { Shoot length } \\
\text { (cm) }\end{array}$ & $\begin{array}{c}\text { Total } P \\
\text { (mg g plant) }\end{array}$ \\
\hline Quartz sand only (-P) & $0.25 \pm 0.11^{\mathrm{a}}$ & $0.11 \pm 0.03^{\mathrm{a}}$ & $19.0 \pm 1.6^{\mathrm{a}}$ & $0.08 \pm 0.05^{\mathrm{a}}$ \\
\hline$-P)+P$. fluorescens & $0.36 \pm 0.08^{\mathrm{a}}$ & $0.13 \pm 0.02^{\mathrm{a}}$ & $22.4 \pm 3.0^{\mathrm{ab}}$ & $0.09 \pm 0.04^{\mathrm{a}}$ \\
\hline$(-\mathrm{P})+$ Serratia $\mathrm{sp}$ & $0.42 \pm 0.08^{\mathrm{a}}$ & $0.20 \pm 0.05^{\mathrm{ab}}$ & $20.6 \pm 0.7^{\mathrm{a}}$ & $0.13 \pm 0.05^{\mathrm{a}}$ \\
\hline$(+\mathrm{RP})^{2}$ & $0.40 \pm 0.10^{\mathrm{a}}$ & $0.19 \pm 0.04^{\mathrm{ab}}$ & $22.4 \pm 1.5^{\text {ab }}$ & $0.07 \pm 0.02^{\mathrm{a}}$ \\
\hline $\mathrm{RP})+P$. fluorescens & $0.29 \pm 0.09^{\mathrm{a}}$ & $0.17 \pm 0.03^{\mathrm{ab}}$ & $20.3 \pm 4.2^{\mathrm{a}}$ & $0.13 \pm 0.03^{\mathrm{a}}$ \\
\hline$(+\mathrm{RP})+$ Serratia $\mathrm{sp}$ & $0.30 \pm 0.08^{\mathrm{a}}$ & $0.31 \pm 0.05^{\mathrm{bc}}$ & $17.6 \pm 2.6^{a}$ & $0.13 \pm 0.03^{\mathrm{a}}$ \\
\hline$(+\mathrm{RP})+3.0 \mathrm{ppm} \mathrm{IP}^{3}$ & $1.21 \pm 0.21^{\mathrm{de}}$ & $0.86 \pm 0.12^{\mathrm{f}}$ & $33.3 \pm 3.1^{\mathrm{d}}$ & $1.20 \pm 0.13^{\mathrm{bc}}$ \\
\hline$(+\mathrm{RP})+3.0 \mathrm{ppm} \mathrm{IP}+P$. fluorescens & $1.06 \pm 0.16^{\mathrm{cd}}$ & $0.51 \pm 0.04^{\mathrm{d}}$ & $31.5 \pm 2.5^{\mathrm{cd}}$ & $1.20 \pm 0.24^{\mathrm{bc}}$ \\
\hline$(+\mathrm{RP})+3.0 \mathrm{ppm}$ IP+ Serratia $\mathrm{sp}$ & $1.20 \pm 0.07^{\mathrm{de}}$ & $0.72 \pm 0.05^{\text {ef }}$ & $29.2 \pm 0.9^{\text {cd }}$ & $1.38 \pm 0.30^{\mathrm{bcd}}$ \\
\hline$(+\mathrm{RP})+3.25 \mathrm{ppm} \mathrm{IP}$ & $1.48 \pm 0.27^{\mathrm{e}}$ & $0.49 \pm 0.07^{\mathrm{d}}$ & $34.6 \pm 2.7^{\mathrm{d}}$ & $1.23 \pm 0.10^{\mathrm{bc}}$ \\
\hline$(+\mathrm{RP})+3.25 \mathrm{ppm} \mathrm{IP}+P$. fluorescens & $0.81 \pm 0.43^{b c}$ & $0.19 \pm 0.10^{\mathrm{ab}}$ & $31.2 \pm 4.2^{\mathrm{cd}}$ & $2.02 \pm 1.09^{\mathrm{de}}$ \\
\hline$(+\mathrm{RP})+3.25 \mathrm{ppm} \mathrm{IP}+$ Serratia $\mathrm{sp}$ & $0.95 \pm 0.06^{\mathrm{cd}}$ & $0.47 \pm 0.05^{\mathrm{d}}$ & $32.0 \pm 3.0^{\text {cd }}$ & $1.53 \pm 0.32^{\text {bcde }}$ \\
\hline$(+\mathrm{RP})+3.5 \mathrm{ppm} \mathrm{IP}$ & $0.88 \pm 0.28^{\mathrm{cd}}$ & $0.47 \pm 0.05^{\mathrm{d}}$ & $27.3 \pm 2.8^{\mathrm{bc}}$ & $1.20 \pm 0.04^{\mathrm{bc}}$ \\
\hline$(+\mathrm{RP})+3.5 \mathrm{ppm} \mathrm{IP}+P$. fluorescens & $0.53 \pm 0.17^{\mathrm{ab}}$ & $0.47 \pm 0.19^{\mathrm{d}}$ & $33.6 \pm 2.5^{\mathrm{d}}$ & $0.85 \pm 0.23^{\mathrm{b}}$ \\
\hline$(+\mathrm{RP})+3.5 \mathrm{ppm}$ IP+ Serratia $\mathrm{sp}$ & $1.05 \pm 0.38^{\mathrm{cd}}$ & $0.55 \pm 0.11^{\mathrm{d}}$ & $32.4 \pm 3.6^{\mathrm{cd}}$ & $1.79 \pm 0.70^{\text {cde }}$ \\
\hline$(+\mathrm{RP})+4.0 \mathrm{ppm} \mathrm{IP}$ & $0.89 \pm 0.16^{\mathrm{cd}}$ & $0.58 \pm 0.09^{\mathrm{de}}$ & $33.1 \pm 5.4^{\mathrm{d}}$ & $2.20 \pm 0.16^{\mathrm{e}}$ \\
\hline$(+\mathrm{RP})+4.0 \mathrm{ppm} \mathrm{IP}+P$. fluorescens & $0.96 \pm 0.05^{\mathrm{cd}}$ & $0.53 \pm 0.09^{d}$ & $30.0 \pm 2.1^{\mathrm{cd}}$ & $1.75 \pm 0.61^{\text {cde }}$ \\
\hline$(+\mathrm{RP})+4.0 \mathrm{ppm}$ IP+ Serratia $\mathrm{sp}$. & $0.91 \pm 0.08^{\mathrm{cd}}$ & $0.44 \pm 0.03^{\mathrm{cd}}$ & $34.7 \pm 2.7^{\mathrm{d}}$ & $2.11 \pm 0.57^{\mathrm{e}}$ \\
\hline
\end{tabular}

${ }^{1}$ Significant differences according to Duncan test at $p<0.05$ levels are indicated by different letters $(\mathrm{n}=3) .{ }^{2} \mathrm{RP}=$ Rock phosphate $(10 \mathrm{ppm}) .{ }^{3} \mathrm{IP}=$ Inorganic phosphatew 
plant experiment an increase of P uptake about 50\% was observed (Table 3). Encapsulation did not inhibit the beneficial effect of rhizobacteria (Bashan et al., 2002). However, the inoculation with immobilized bacteria was not higher significantly on dry matter and $\mathrm{P}$ absorption with the other levels of $\mathrm{P}$.

In the other hand, the use of high starch concentration $(47 \%)$ on matrix encapsulation increases cells adhesion to starch. Previous studies on probiotic and rhizobacteria have revealed cells adhesion to starch granules (Crittenden et al., 2001; Schoebitz et al., 2009b). It has been demonstrated anassociation between cells adhesion and its use as a carbon source substrate by cells (Crittenden et al., 2001). Increasing the growth plant effects, the beads can be forced to release the bacteria by mechanical crushing, while the intact beads can serve for progressive release (Rekha et al., 2007). Nevertheless, the use of starch increase the dry matter of the beads (Schoebitz et al., 2012) to give better mechanical resistance (Tal et al., 1999) and allow a high cells survival and establishment of the microbial inoculants on soil conditions.

\section{Conclusion}

There is huge potential for the use rhizobacterias microbial inoculants for a wide variety of plants to reduce the chemical fertilizers input. Characterizing and developing innovative rhizobacteria formulation helps in the selection of potential candidates as biofertilizers. In that way, the innovative field of bioencapsulation of phosphate solubilizing bacteria achieves certain desirable effects, such as stabilization, protection and progressive release of these microorganisms for targeted agricultural applications. This study concludes preliminarily that immobilization of $P$. fluorescens and Serratia sp in alginate-starch beads was effective in dissolving insoluble phosphate. Rhizobacterial immobilization represents a promising alternative as inoculant carrier for wheat plant in sand potted experiment. Alternatively, the immobilized microorganisms confer a gradual cells release that achieves long-term fertilizing effects. Additionally, each bead into the soil, may act as a minibioreactor increasing the initial cells concentration. This can reduce cost associated with the multiplication of bacteria. Furthermore, if there are several beads around the rhizosphere, each bead may act as an independent unit, which increases the cells concentration enhancing the microbial inoculants efficacy and $\mathrm{P}$ uptake by wheat plants.

\section{Acknowledgementsw}

This study is part of the project funded by Fund for the Promotion of Scientific and Technological Development (FONDEF D08I 1039), National Commission for Scientific and Technological Research, Government of Chile.

\section{References}

Adesemoye, A.O., Kloepper, J.W. 2009. Plant-microbes interactions in enhanced fertilizer-use efficiency. Appl Microbiol Biotechnol. 85, 1-12.

Bashan, Y. 1998. Inoculants of plant growth-promoting bacteria for use in agriculture. Biotechnol. Adv. 16, 729-770.

Bashan, Y., Hernandez, J.P., Leyva, L.A., Bacilio, M. 2002. Alginate microbeads as inoculant carriers for plant growth-promoting bacteria. Biol. Fertil. Soils. 35, 359-368.

Bashan, Y., Holguin, G., de-Bashan, L.E. 2004. Azospirillum-plant relationships: physiological, molecular, agricultural, and environmental advances (1997-2003). Can. J. Microbiol. 50, 521-77. 
Bashan, Y., Kamnev, A.A., de-Bashan, L.E. 2012. Tricalcium phosphate is inappropriate as a universal selection factor for isolating and testing phosphatesolubilizing bacteria that enhance plant growth: a proposal for an alternative procedure. Biol. Fertil. Soils. DOI 10.1007/s00374-012-0737-7

Cassidy, M.B., Lee, H., Trevors, J.T. 1996. Environmental applications of immobilized microbial cells: a review. Journal of Industrial Microbiology. 16, 79-101.

Crittenden, R., Laitila, A., Forssell, P., Matto, J., Saarela, M., Mattila-Sandholm, T., Myllarinen, P. 2001. Adhesion of Bifidobacteria to Granular Starch and Its Implications in Probiotic Technologies. Applied and Environmental Microbiology. 67, 3469-3475.

Edi-Premono, M., Moawad, M.A., Vleck, P.L.G. 1996. Effect of phosphate solubilizing Pseudomonas putida on the growth of maize and its survival in the rhizosphere. Indonesian Journal of Crop Science. 11, 13-23.

Fages, J. 1992. An industrial view of Azospirillum inoculants: formulationand application technology. Symbiosis. 13, 15-26.

Hickman, M.V. 1999. Controlled-release pesticide formulations from cornstarch. in: H.B. Scher (Ed.) Controlled-release delivery systems for pesticides. Marcel Dekker Inc, New York, pp. 153-171.

Hoagland, D.R., Arnon, D. 1950. The water culture method of growing plants without soil. California Agricultural Experiment Station. 347, 39.

John, R.P., Tyagi, R.D., Brar, S.K., Surampalli, R.Y. Prevost, D. 2011. Bio-encapsulation of microbial cells for targeted agricultural delivery. Crit. Rev. Biotechnol. 31, 211-226.
Kim, I.Y., Pusey, P.L., Zhao, Y., Korban, S.S., Choi, H., Kim, K.K. 2012. Controlled release of Pantoea agglomerans E325 for biocontrol of fire blight disease of apple. J. Control Release. 161, 109-15.

Kim, K.I., Baek, Y.J., Yoon, Y.H. 1996. Effects of rehydration media and immobilisation in calciumalginate on the survival of Lactobacillus casei and Bifidobacterium bifidum. Korean J. Dairy Sci. 18, 193-198.

Murphy, J., Riley, J.P. 1962. A modified single solution method for determination of phosphate in natural waters. Analytica Chimica Acta. 27, 31-36.

Naseby D.C., Lynch J.M. 1997. Rhizosphere soil enzymes as indicators of perturbation caused by a genetically modifed strain of Pseudomonas fluorescens on wheat seed. Soil Biol. Biochem. 29, 1353-1362.

Nautiyal, C.S., Bhadauria, S., Kumar, P., Lal, H., Mondal, R., Verma, D. 2000. Stress induced phosphate solubilization in bacteria isolated from alkaline soils. FEMS Microbiol. Lett. 182, 291-296.

Nico, M., Ribaudo, C., Gori, J.I., Cantore, M.L., Curá, J.A. 2012. Uptake of phosphate and promotion of vegetativegrowth in glucose-exudingrice plants (Oryzasativa) inoculated with plant growthpromotingbacteria. Applied Soil Ecology. 61, 190-195.

Rekha, P.D., Lai, W.A., Arun, A.B., Young, C.C. 2007. Effect of free and encapsulated Pseudomonas putida CC-FR2-4 and Bacillus subtilis CC-pg104 on plant growth under gnotobiotic conditions. Bioresour. Technol. 98, 447-51.

Rodriguez, H., Fraga, R. 1999. Phosphate solubilizing bacteria and their role in plant growth promotion. Biotechnol. Adv. 17, 319-339. 
Schoebitz, M., Ribaudo, C., Pardo, M., Cantore, M., Ciampi, L., Curá, J.A. 2009a. Plant growth promoting properties of a strain of Enterobacter ludwigii isolated from Lolium perenne rhizosphere. Soil Biol .Biochem. 41, 1768-1774.

Schoebitz, M., Simonin, H., Poncelet, D. 2009b. Rhizobacteria adhesion to starch granules XVIIth International Conference on Bioencapsulation. Bioencapsulation Research Group, Groningen, Netherlands.

Schoebitz, M., Simonin, H., Poncelet, D. 2012. Starch filler and osmoprotectants improve the survival of rhizobacteria in dried alginate beads. J. Microencapsul. 29, 532-538.

Tabatabai, M.A., Bremmer, J.M. 1969. Use of p-nitrophenyl phosphate for assay of soil phosphatase activity. Soil Biol. Biochem. 1, 301-307.
Tal, Y., van Rijn, J., Nussinovitch, A. 1999. Improvement of mechanical and biological properties of freeze-dried denitrifying alginate beads by using starch as a filler and carbon source. Appl. Microbiol. Biotechnol. 51, 773-779.

Vassilev, N., Toro, M., Vassileva, M., Azcon, R., Barea, J.M. 1997. Rock phosphate solubilization by immobilized cells of Enterobacter $\mathrm{sp}$. in fermentation and soil conditions. Bioresour .Technol. 61, 29-32.

Vassilev, N., Vassileva, M., Azcon, R., Medina, A. 2001. Application of free and Ca-alginate-entrapped Glomus deserticola and Yarowia lipolytica in a soilplant system. J. Biotechnol. 91, 237-42.

Wu, Z., Guo, L., Qin, S., Li, C. 2012. Encapsulation of $R$. planticola Rs-2 from alginate-starch-bentonite and its controlled release and swelling behavior under simulated soil conditions. J. Ind. Microbiol. Biotechnol. 39, 317-27. 